\title{
A Doctrinal Review of Visual Art from Islamic Religious Institution in Malaysia
}

\author{
Ishak Ramli¹, Mumtaz Mokhtar², Mohamad Noorman Masrek³, Zarlina Mohamad Zamri4 \\ ${ }^{1}$ Faculty of Art and Design, Universiti Teknologi MARA, Seri Iskandar Campus, 32610 Perak, Malaysia \\ ${ }^{2}$ Faculty of Art and Design, Universiti Teknologi MARA, Shah Alam, 40450 Selangor, Malaysia \\ ${ }^{3}$ Faculty of Information Management, Universiti Teknologi MARA, Puncak Perdana Campus, 41750 Selangor, Malaysia \\ ${ }^{4}$ Academy of Language Studies, Universiti Teknologi MARA, Seri Iskandar Campus, 32610 Perak, Malaysia \\ ibr_86@yahoo.com, mumtazmikaeil@gmail.com, rahimi313@uitm.edu.my, mnoormanm@gmail.com, zarlinamz@gmail.com \\ Tel: +60132825913
}

\begin{abstract}
This paper aims to gather doctrinal reference regarding visual art from Malaysian Islamic Religious institutions; and to analyze the content of all collections (objective 1) that are related to the presentation of visual art as discussed in the perspective of Islamic Shariah; by using a systematic literature review approach. The findings from the doctrinal report on visual art showed that its discussion revolved only around the explanation of imagery in visual art which involved 6 types of visible subjects. This comprehensive collection will become a guideline in producing visual artwork that comply with Islamic Shariah.
\end{abstract}

Keywords: Doctrinal review; guideline; fatwa; visual art

eISSN: 2398-42870 2020. The Authors. Published for AMER ABRA cE-Bsby e-International Publishing House, Ltd., UK. This is an open access article under the CC BYNC-ND license (http://creativecommons.org/licenses/by-nc-nd/4.0/). Peer-review under responsibility of AMER (Association of Malaysian Environment-Behaviour Researchers), ABRA (Association of Behavioural Researchers on Asians) and CE-Bs (Centre for Environment-Behaviour Studies), Faculty of Architecture, Planning \& Surveying, Universiti Teknologi MARA, Malaysia.

DOI: https://doi.org/10.21834/ebpj.v5iSI3.2533

\subsection{Introduction}

As a sovereign nation with Islam as the official religion, it is a must for each Malaysian (especially the Muslims) to adhere to the essence of Islamic teachings in the context of worship (ibadah) as well as its application in other aspects of daily life. Visual art cannot be separated from its compliance with the core of Islamic teachings not only in the production of products by the artists, but it also involves the display of images in those items. This is in line with the Maqasid Shariah requirement, which aims to overcome harmful (mafsadah) as part of the effort to apply good (maslahah) (Hussain, 2012). If one discusses the scope of Shariah-compliant visual art, it involves the images produced in Muslim artists' artwork and images created to be exhibited to the audience (artwork by Muslims and non-Muslims) (Ramli, Masrek, Ab Gani, et al., 2017a; Ramli, Masrek, Gani, et al., 2017; Ramli et al., 2019). A general issue that needs to be addressed in this situation is 1) What are the permissible images or visual subjects that can be produced by Muslim visual artists in visual art?; and 2) What are the pictures or visible items that are allowed to be viewed by all Muslim visual artists in visual arts artwork? Both questions are linked to compliance with Islamic Shariah by the Islamic visual artists (in the context of production and appreciation) as illustrated in Fig. 1.

However, some local visual artists produced visual artwork that transcends the norm and guidelines of local culture as well as Islam. Any issue and situations about visual art must be emphasized by relevant authorities such as the State Islamic Religious

eISSN: 2398-4287C 2020. The Authors. Published for AMER ABRA cE-Bsby e-International Publishing House, Ltd., UK. This is an open access article under the CC BYNC-ND license (http://creativecommons.org/licenses/by-nc-nd/4.0/). Peer-review under responsibility of AMER (Association of Malaysian Environment-Behaviour Researchers), ABRA (Association of Behavioural Researchers on Asians) and cE-Bs (Centre for Environment-Behaviour Studies), Faculty of Architecture, Planning \& Surveying, Universiti Teknologi MARA, Malaysia.

DOI: https://doi.org/10.21834/ebpj.v5iSI3.2533 
Council or Department of Islamic Development (JAKIM). Nevertheless, there is a division of job scope and responsibilities between these two departments: issues regarding Islam are put under the duties of the Sultans of each state except for a few states and federal states. For these states and federal states, the Islamic jurisprudence is in the hands of Yang Di Pertuan Agong. This is clearly stated in the Malaysian Federal Constitution that provides the scope and jurisdiction concerning Islam (Commissioner of Law, 2010). On the other hand, the extent of visual art scope discourse in each State Religious Council and JAKIM has never been comprehensively studied. Based on this predicament, this research aims to: 1) collect doctrinal references concerning visual art from Islamic institutions in Malaysia; and 2) analyze all contents of collected materials (objective 1) that are related to a presentation of visual art as discussed from the perspective of Islamic Shariah.

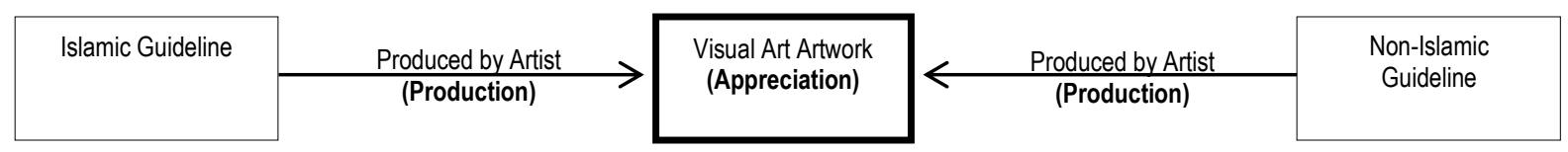

Fig. 1: Visual artwork production by artists for appreciation (Source: Illustrated by the author)

This research article is arranged based on a second sub-topic that discusses the background of visual art as referred to as the research scope. Besides, the development of a research framework is also taken into consideration - visual art that is related to the Islamic Shariah study which will become significant factors in systematically analyzing the results from discussions in the literature review. The third sub-topic will explain the procedures taken in arranging the literature review, the process involved in the accumulation of research review and their results. Moreover, the fourth sub-topic will provide discussions on the analytical process of literature reviews, and the fifth sub-topic will present the findings on visual art scope which has been discussed in the State Islamic Religious Councils' fatwa and enactment. Besides, the sixth sub-topic will discuss the limitation and potential future research. Lastly, the seventh sub-topic provides the conclusion to this research.

\subsection{Literature Review on Visual Art}

Visual art is a part of a diverse form of art that has existed since ages ago. Other than musical, theatrical, film, dance and comic art (just to name a few), visual art's development has been given due attention. In the attempt to define, according to National Visual Art Development Board, visual art is an art that is produced from suitable mediums, technique, process or visual sense and it exists in a permanent form (Commissioner of Law Revision, 2015).

\subsection{Visual Art Background in Malaysia}

Visual art in Malaysia has existed since the age of traditional to the modern age visual art known today. The development of local visual art is mentioned in its definition where the production of this art is appealing to the sight, and the product is permanent in the form (Commissioner of Law Revision, 2015).

Traditional visual art development which has the form follow function, in which each artefact produced, must possess the basis of its capacity. This can be observed in several traditional art artefacts such as songket cloth (to wear for features), keris (for safety and battle), wood carvings at houses (for decorative purposes and ventilation), ceramic pottery (for decoration and to keep the water) and the list goes on. In all, traditional visual art (or also known as the Malay craft) has existed in Malaysia (previously called Tanah Melayu) for ages (Noh, Haron, Samian, \& Hasan, 2015). Today, traditional visual art continues to thrive, and there are many initiatives to preserve it such as the establishment of the National Craft Institute, Craft Museum and many more.

As for modern visual art development, it started from the pre-independent years, specifically around the 1930s (Mahamood, 2001, 2005). At the same time, this positive development happened when several Malaysian students were given the scholarship to pursue their studies, specifically in Visual Art studies, in Europe. With experiences gained in foreign countries, the visual art patterns produced had western influences, and they paved their way into important art exhibitions in Malaysia.

At the same time, the elements of culture and religion were beginning to surface in these artists' artwork. Moreover, after Malaysian independence in 1957, when the Malaysian Federal Constitution (1963) was implemented, local visual art artists had strong urges to apply images and cultural as well as local religious values into their work (Commissioner of Law, 2010). This phenomenon flourished when in the process of producing their artwork, visual artists influenced by the World Islamic resurgence (Mahamood, 2001; Sayyid Muhammad, 1984) and referred to National Cultural Policy ("Dasar Kebudayaan Kebangsaan," 1971) which had three crucial elements namely: 1) based on the regional culture; 2) other suitable cultural factors which can be accepted; 3 ) Islam became the most essential factor in the development of national culture. Consequently, this situation had contributed to the keen interest of local visual artists to incorporate Islam into their artwork (Hamidon, 2012; Mahamood, 2001; Wan Mohd Daud, 2017; Wan Mohd Daud, Mohd Zain, \& Amin, 2013). With this situation, another critical genre, Islamic Art came into the scene: however, this type of art was only popular between the 80s and the end of 90s era (Esa, 1997; Hamidon, 2012; Mohd Zain, 1996, 2000, 2006, 2012; Sanusi, 2000, 2016; Sayyid Muhammad, 1984; Seyedi, Hamidon, \& Ross, 2017; Wan Mohd Daud et al., 2013; Wan Mohd Daud, Mohd Zain, \& Amin, 2014).

In 1987, an effort was taken by the National Fatwa Council for the 16th Administration of Islamic Religious Affairs (MKI) to publish a reference material for visual art artists: it offered Guidelines and Explanation about Visual Art from Islamic Perspective (Jabatan 
Kemajuan Islam Malaysia, 1987; Ramli, Masrek, Ab Gani, et al., 2017a). These guidelines were crucial to the situation and development of modern visual art which was based on western languages and methods. Nevertheless, the guidance must be reviewed again to suit the changing contemporary visual art that is advanced in its exploration of medium, subjects or image, style, and philosophy; to assist and provide the latest guidelines to visual art artists.

\subsection{Visual Art Model Background and Research Framework}

The entire art basics (inclusive of film, music, theatre, and other art genres) are based on three main components, namely subject, form, and content (Ocvirk, Stinson, Wigg, Bone, \& Cayton, 2006). These three components were crucial in deconstructing meaning, purpose, and medium for each artefact produced.

There were several types of subjects, like a subject-matter of which the choice of matter by the artist was based on issues or themes that were referred to in the production of visual artwork. Similarly, there was an explanation that the subject is an entity that represented a chosen issue or theme to be interpreted into an artwork. Another approach was the main subject became the platform for the main narrative for any artwork and the other was a supporting subject that gave an added value to the chosen main topic. As for the form, it was discussed through several sections such as 1. Subject formation characteristic (art element and principle were the basis for the production of a visual art artwork); 2. Work composition (the chosen layout design subject was based on the position of the matter be it the primary or supporting subject in the composition. It involves the space in an artwork, namely the perspective or flat space as well as others); 3 . Artwork style (styling includes several important several characteristics in presenting a visual art artwork such as imitation, stylization or abstraction. An individual style or art genre often influenced this); 4 . Artwork medium is the technique in producing artwork is based on the types of chosen disciplines such as drawing, painting, printing, sculpture and new media art, among others. The medium used depended on two main elements; 1 . Reference in artwork (to choose the subject and arrange the composition); and 2. Narrative and meaning in artwork (it could be positive and negative to convey messages to the audience).

In this study, based on the above discussion, the research framework depends on the presentation of the visual art artwork that involved two components: subject and form. Debate on the "subject" is more inclined on types of images or pictures or objects discussed; the "form" is related to visual style and focused medium of artwork in the discussion of a doctrinal reference in the Malaysian Islamic Religious Institutions.

\subsection{Review Method}

This study uses the structured literature review approaches (also known as systematic literature review Shaffril, Krauss, \& Samsuddin, 2018), which are combined through suggestions of Vom Brocke et al. (2009) and Webster and Watson (cited from Kowalczyk, 2017). Kowalczyk (2017) has neatly arranged a combined procedure to obtain high validity and reliability in the process of going through a collection of guidelines, enactments, and fatwa regarding visual art from the perspective of Islam from Malaysian Islamic Religious Institutions. In the context of this research, validity is the precision in the identification and administrating the sources, including the choice of bank data resources and exact search terms. As for reliability in this write-up, it refers to replicability in the process of searching, and it is achieved through precise arrangement and selection (Vom Brocke et al., 2009). Based on this explanation, this study repeats the procedures conducted by Kowalczyk (2017) that are: 1. review scope; 2. search term; 3. inclusion/exclusion criteria; 4. data sources and search process; and 5. data extraction and analysis.

\subsection{Review Scope}

In this sub-topic, Kowalczyk (2017) explained the emphasis given by Vom Brocke et al. (2009) through the taxonomy of suggestions arranged by Cooper in the arrangement of previous studies cope. The objective of this paper is to collect and analyze past doctrinal materials on the guidelines, enactment, and fatwa produced by the Malaysian Religious Islamic institutions regarding visual art. Through these approaches, a much clearer view was gained on: What are the types of visual art presentations which are part of the discussion in Islamic Religious institutions in Malaysia? Based on this situation, what is the improvement which is required for the local visual art scene as discussed by Islamic Religious institutions? The researcher put in order the collection of doctrinal studies based on diverse presentations in visual art. Hence, the scope of previous studies is focused on Malaysian doctrinal studies which emphasize discussions on visual art issues.

\subsection{Search Terms}

In this topic, the researcher is directed to search for meaningful words or terminology, as mentioned by Vom Brocke et al., (2009) (as cited from Kowalczyk, 2017). As explained in the previous sub-topic, the researcher will study prior doctrinal reference, which is inclined to discuss the matters about visual and visual art from Malaysian Islamic Religious institutions. During the early stage of the studies, the researcher found two topics namely: 1. visible subject which appeared in the discussion that is inclusive of living things, non-living things, religious symbols and writings; and 2. visual style that was discussed was inclusive of imitation, representation or abstraction. The researcher has discussed with four scholars in visual art to list relevant words and their connection to one another. Using these newly obtained words, the researcher did a search test run using several data platforms to achieve terminology suitability: certain words require only one name and others need a combination. Therefore, the relevant terminology in the search for doctrinal data for visual art are: 1. art; 2. draw; 3. picture; 4. calligraphy; 5. khat; 6. symbol; 7. logo; 8. signs; 9. shape; 10. appearance; 11. colour; 12. printing; 13. printed; 14. write; and 15. writing. 


\subsection{Inclusion and Exclusion Criteria}

In arranging the procedure to process the choice of guidelines and fatwa about visual art, the researchers took into consideration inclusion and exclusion criteria to fulfil the objective of this study. These criteria add more transparency to the research, and it is not restricted to the search for the reference procedure but also for the process involving the re-evaluation of chosen references. To fulfill the inclusion criteria, the choice of guideline and fatwa must be inclined towards explaining the visual art criteria such as issues regarding the title, content, example, and results. In the evaluation related to exclusion criteria, this study is focused on the presentation of visual artwork. However, several presentations were discussed. Among the types of visual artwork mentioned by the Malaysian Islamic Religious institutions were: 1. Two-dimensional - 2D (involve paintings, illustration, and items related to static presentation); 2. Three-dimensional - 3D (include a figure that is carved to resemble the actual object); and 3. Four-dimensional $-4 \mathrm{D}$ (it is related to the issue of movement, time/duration such as animation and film). The researcher was focused on the discussion on a two-dimension presentation relative to visual artwork. Documents that contained discussions on other matters were excluded from the study.

\subsection{Data Sources and Search Process}

In choosing and collecting the most relevant data, Kowalczyk (2017) explained that, Webster and Watson emphasized on the choice of reference must be made through the scientific database. However, this study has set that the experimental data platform was more directed towards doctrinal text from the Malaysian Islamic Religious institutions. Based on the researcher's exploration, to collect a list of doctrinal texts in the Malaysian Islamic Religious institutions, this study referred to one database which was prepared by the Department of Islamic Development Malaysia (JAKIM) known as e-SMAF Sumber Maklumat al-Ahkam al-Fiqhiyyah (Jabatan Kemajuan Islam Malaysia, n.d.).

Table 1. Record of doctrinal reference in the SMAF database from the Sumber Maklumat al-Ahkam al-Fiqhiyyah

\begin{tabular}{|c|c|c|c|c|c|}
\hline \multirow[b]{2}{*}{ Features } & \multicolumn{3}{|c|}{ The Amount of Records in e-SMAF } & \multirow[b]{2}{*}{ Guidelines } & \multirow{3}{*}{$\begin{array}{c}\text { Amount of } \\
\text { Doctrinal reference } \\
1,399\end{array}$} \\
\hline & $\begin{array}{l}\text { Question and Answer, } \\
\text { Fellow of Law }\end{array}$ & $\begin{array}{l}\text { Fatwa / Perspective } \\
\text { of law }\end{array}$ & Scholars' views & & \\
\hline $\begin{array}{l}\text { The number according to the type of } \\
\text { reference }\end{array}$ & 216 & 1,101 & 45 & 37 & \\
\hline
\end{tabular}

(Source: Ishak Ramli prepared tabulated data on 25 July 2018)

This SMAF data platform collected all the decisions related to fellow of law, fatwa/ perspective of law, scholars' views and guidelines for all Malaysian Islamic institutes. In Table 1, the amount of all records in the e-SMAF database was listed. Based on the data platform, the researcher identified that there was a searching method via e-SMAF that could only accommodate one word in each search.

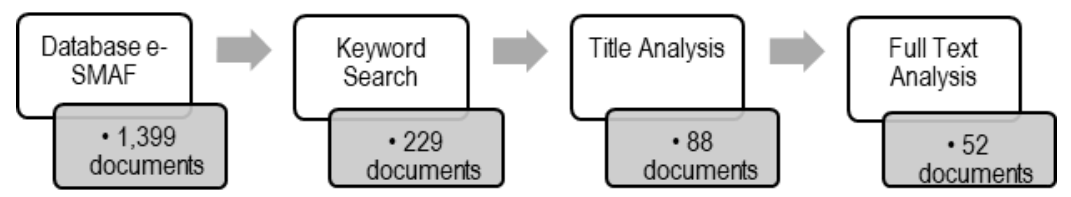

Fig. 2: the Search process

(Source: Figure was prepared by Ishak Ramli)

Table 2. Record of doctrinal reference regarding visual art based on search

\begin{tabular}{|c|c|c|c|c|c|c|c|c|c|c|c|c|}
\hline \multicolumn{13}{|c|}{ Type and Number of Discussion from Islamic Institutes } \\
\hline \multirow[b]{2}{*}{ Item } & \multicolumn{3}{|c|}{ Q \& A with the Fellow of Law } & \multicolumn{3}{|c|}{ Fatwa / Perspective of law } & \multicolumn{3}{|c|}{ Scholars Views } & \multicolumn{3}{|c|}{ Guidelines } \\
\hline & $\begin{array}{l}\text { Keywords } \\
\text { Search }\end{array}$ & $\begin{array}{c}\text { Title } \\
\text { Analysis }\end{array}$ & $\begin{array}{c}\text { Full } \\
\text { Text } \\
\text { Analysis }\end{array}$ & $\begin{array}{c}\text { Keywords } \\
\text { Search }\end{array}$ & $\begin{array}{c}\text { Title } \\
\text { Analysis }\end{array}$ & $\begin{array}{c}\text { Full } \\
\text { Text } \\
\text { Analysis }\end{array}$ & $\begin{array}{l}\text { Keywords } \\
\text { Search }\end{array}$ & $\begin{array}{c}\text { Title } \\
\text { Analysis }\end{array}$ & $\begin{array}{c}\text { Full } \\
\text { Text } \\
\text { Analysis }\end{array}$ & $\begin{array}{c}\text { Keywords } \\
\text { Search }\end{array}$ & $\begin{array}{c}\text { Title } \\
\text { Analysis }\end{array}$ & $\begin{array}{c}\text { Full } \\
\text { Text } \\
\text { Analysis }\end{array}$ \\
\hline Art & - & - & - & 8 & - & - & - & - & - & 1 & 1 & 1 \\
\hline Painting & - & - & - & 6 & 5 & 5 & - & - & - & - & - & - \\
\hline Pictures & 7 & 3 & 3 & 11 & 6 & 4 & - & - & - & - & - & - \\
\hline Calligraphy & - & - & - & 7 & 7 & 7 & - & - & - & - & - & - \\
\hline Khat & 1 & - & - & 19 & 8 & 6 & - & - & - & - & - & - \\
\hline Symbol & - & - & - & 1 & 1 & 1 & - & - & - & - & - & - \\
\hline Logo & - & - & - & 4 & 4 & 3 & - & - & - & - & - & - \\
\hline Sign & - & - & - & 9 & 9 & 6 & 1 & 1 & 1 & - & - & - \\
\hline Shape & 3 & - & - & 35 & 10 & 2 & 1 & - & - & - & - & - \\
\hline Form & 11 & 1 & - & 52 & 4 & 1 & 3 & - & - & - & - & - \\
\hline Color & 2 & 1 & 1 & 9 & - & - & 1 & - & - & - & - & - \\
\hline Printing & 3 & 2 & 2 & 2 & 1 & - & - & - & - & - & - & - \\
\hline $\begin{array}{l}\text { Printed } \\
\text { materials }\end{array}$ & - & - & - & 5 & 1 & - & 1 & - & - & - & - & - \\
\hline Write & 1 & 1 & 1 & 17 & 12 & 5 & - & - & - & - & - & - \\
\hline Writing & 1 & 1 & - & 8 & 7 & 2 & 1 & 1 & 1 & - & - & - \\
\hline $\begin{array}{l}\text { Number of } \\
\text { Reference }\end{array}$ & 29 & 9 & 7 & 191 & 75 & 42 & 8 & 2 & 2 & 1 & 1 & 1 \\
\hline
\end{tabular}


From all the 1,399 documents record (refer to fig. 2) from the SMAF database, the researcher had performed a document search based on the keywords listed. As a result of using these words, 229 documents were recorded. However, the search process had gone through a selection stage and analyses on document titles: in the end, 88 papers were selected as they were suitable with the research scope which was the doctrinal reference discussions on visual art presentation. After the analyses on all documents, there were several repetitive materials; in the end, only 52 papers were analyzed.

In Table 2, the researcher has listed detailed data that were derived from the e-SMAF database. The visual provides a clearer picture from the accessible documents which were analyzed and chosen to become a collection of doctrinal reference sources regarding visual arts from the Islamic institutions in Malaysia. As a result, 52 shortlisted documents were processed through full-text analyses and the researcher listed discussions related to visual art.

\subsection{Data Extraction and Analysis Procedures}

Based on 52 last chosen documents, the full information had been refined using the extraction form. Other than identification based on the necessary information (title, year and reference source), the researchers also extract information regarding attesting from the document. This was because, in the issue of the document certifying, one statement from the Mufti could not be considered as fatwa until it had been certified (Majlis Agama Islam Selangor, 1989). However, the issue of the document certifying was not the basis for the choice in document selection since the number was reduced from 52 to 24 materials only. Hence, all materials which had been selected would be analyzed without taking into consideration the issue of attesting a certificate.

Having completed the process of data extraction (full-text analysis), on the section for 'fatwa/perspective of law', there was a repetitive discussion between the Majis Muzakarah Fatwa Kebangsaan and State fatwa Council. This happened because the study at the national level had to be done at the state level for the process of attesting it. From all 42 documents in the 'fatwa/perspective of law' section, which had been analyzed, only 29 papers were selected to be utilized for this study. Therefore, there were only 39 documents that were included in the discussion.

In analyzing the extracted information from the chosen documents, the researcher referred to the research framework that was the type of visual art presentation discussed (subject, style, and medium of presentation). In the process of analyses, all kinds of visual art presentations which were discussed by the Malaysian Islamic Religious institutions were identified to ensure one comprehensive data could be collected. Each document went through the process of analyses on 1. the subject brought forth with the consideration of the section highlighted; it could be all-inclusive, partly or only a fraction of it; 2 . the style used was also taken into account since it influenced the nature of a subject - whether or not it was perfect; 3 . the medium of presentation was taken into account since the discussion scope had differentiated the function of that visual artwork. All of the discussions will be in line with the research framework.

\subsection{Results of The Structured Literature Review}

In the list of all data from the Malaysian Islamic institutions that will be used in this research, 39 documents are divided into these categories: 1. Question and answer from the Fellow of Law (7 documents); 2. Fatwa/perspective of law (29 documents); 3 . Scholars view (2 documents); and 4. Guidelines (1 document).

All of the documents involve the presentation of visuals in various aspects. In the context of visual art, any matter which is related to the visual presentation is the Language that must be discussed. In 39 doctrinal reference documents, there were only 16 documents (4 documents repeatedly reviewed. Only 12 documents included in table 3 ) that specifically covers the issues of visual art ( 3 questions and answer with the fellow of law, 12 fatwa/perspective of law and 1 guideline). 23 documents were seen concerning the visual matters that can be linked to this study (4 questions and answer, 17 fatwa / the perspective of law and 2 scholars' opinion). Nevertheless, in this study, 23 documents were excluded from the discussion due to the publication constraint which limits the number of pages for this write-up.

\subsection{Doctrinal Document on the Specific Discussion of Visual Art (Subjects and Styles)}

Based on some identified documents, there is repeated discussion related to several visual subjects and styles in visual art (see Table 3). The analysis provides the image that visual art matters have been taken into consideration by Malaysian Islamic Religious institutions. Some of the visible subjects for two-dimension visuals discussed are 1. Living subjects (humans and animals); 2. Nonliving items (plants, flowers, trees, river, rocks); 3. Great human subject (previous prophets, Prophet Muhammad, his Family, Companions R. hum); 4. Quranic verses; 5. Symbols of other religions; and 6. Combined subjects (Quranic verses or khat was writing in the form of kites, flowers, plants, humans, animals). For visual style, the researchers found only representation and stylization approaches.

Table 3. Full-text analysis

\begin{tabular}{|c|c|c|c|c|c|c|}
\hline \multicolumn{7}{|c|}{ Discussions on Doctrinal Reference Documents Linked to Visual Arts } \\
\hline No. & Document & Year & Document Type & Visual Subject & Visual Style & Repeated Results \\
\hline 1. & $\begin{array}{l}\text { Negeri Sembilan Mufti } \\
\text { Department }\end{array}$ & 2009 & $\begin{array}{c}\text { Fatwa / Perspective } \\
\text { of law }\end{array}$ & Human (Prophet Muhammad) & Representation & - \\
\hline 2. & Malacca Islamic Religious Affair & 2009 & $\begin{array}{c}\text { Fatwa / Perspective } \\
\text { of law }\end{array}$ & $\begin{array}{l}\text { Human (Prophet Muhammad, his } \\
\text { Family and Companions) }\end{array}$ & Representation & \\
\hline 3. & National Fatwa Council & 2008 & Fatwa / Perspective & Items or logo with symbols of other & Representation & Wilayah Persekutuan \\
\hline
\end{tabular}




\begin{tabular}{|c|c|c|c|c|c|c|}
\hline & & & of law & religions & & $\begin{array}{c}(2015,2012) \\
\text { Negeri Sembilan (2014) }\end{array}$ \\
\hline 4. & Johor Mufti Department & 2008 & $\begin{array}{c}\text { Fatwa / Perspective } \\
\text { of law }\end{array}$ & $\begin{array}{l}\text { Khat in the form of human or } \\
\text { animal }\end{array}$ & Stylization & - \\
\hline 5. & National Fatwa Council & 2005 & $\begin{array}{c}\text { Fatwa / Perspective } \\
\text { of law }\end{array}$ & $\begin{array}{l}\text { The Quranic verse in the shape of } \\
\text { kites, plants, flowers }\end{array}$ & Stylization & Negeri Sembilan (2014) \\
\hline 6. & Kedah Mufti Department & 1996 & $\begin{array}{c}\text { Fatwa / Perspective } \\
\text { of law }\end{array}$ & $\begin{array}{l}\text { Khat in the form of human or } \\
\text { animal }\end{array}$ & Stylization & - \\
\hline 7. & $\begin{array}{c}\text { Department of Islamic } \\
\text { Development Malaysia (JAKIM) }\end{array}$ & 1987 & Guideline & $\begin{array}{l}\text { Humans who cover their aurah, } \\
\text { animals, dolls, trees, plants, living } \\
\text { and non-living things }\end{array}$ & Representation & - \\
\hline 8. & Kelantan Mufti Department & 1970 & $\begin{array}{c}\text { Fatwa / Perspective } \\
\text { of law }\end{array}$ & $\begin{array}{l}\text { Living objects that are animals and } \\
\text { humans (physically perfect, } \\
\text { physically not whole) }\end{array}$ & Representation & - \\
\hline 9. & Kelantan Mufti Department & 1970 & $\begin{array}{c}\text { Fatwa / Perspective } \\
\text { of law }\end{array}$ & Humans (not covered) & Representation & - \\
\hline 10. & $\begin{array}{c}\text { Department of Islamic } \\
\text { Development Malaysia (JAKIM) }\end{array}$ & n.d. & $\begin{array}{l}\text { Question and } \\
\text { answer from the } \\
\text { Fellow of Law }\end{array}$ & $\begin{array}{l}\text { Living objects (Animal and human), } \\
\text { Non-living objects (Tress, rocks, } \\
\text { river) displayed in the mosque }\end{array}$ & Representation & - \\
\hline 11. & $\begin{array}{c}\text { Department of Islamic } \\
\text { Development Malaysia (JAKIM) }\end{array}$ & n.d. & $\begin{array}{l}\text { Question and } \\
\text { answer from the } \\
\text { Fellow of Law }\end{array}$ & Human pictures & Representation & - \\
\hline 12. & $\begin{array}{c}\text { Department of Islamic } \\
\text { Development Malaysia (JAKIM) }\end{array}$ & n.d. & $\begin{array}{l}\text { Question and } \\
\text { answer from the } \\
\text { Fellow of Law }\end{array}$ & $\begin{array}{l}\text { Pictures or videos of humans } \\
\text { sinning }\end{array}$ & Representation & - \\
\hline
\end{tabular}

(Source: Ishak Ramli prepared table)

As for visual art field that was discussed; based on observation and analysis by the researcher, the specific visual art fields mentioned in the discussion were painting, drawings, sculpture, khat writing, photography, children's toys, carving, craft, textile, advertisement, fashion, video, and animation. In all, the scope of this research is based on two-dimensional visual art, discussions on sculpture, video and animation art as well as animation, carvings and children's toys are not included in the debate.

\subsection{Discussion of Results}

Based on the results derived from the discussion in the previous sub-topics, there are limitations in the discourse about visual art from various Malaysian Islamic institutions. These issues involve several factors, such as: 1 . There was no effort to collect all kinds of visible subjects and styles comprehensively; bring them up in the discourse from the perspective of scholars in Islamic Shariah; 2. Visual art development is exclusive; the lack of involvement from different levels of the society to comprehend visual art except for those who are directly involved in visual art, visual art enthusiast and students of visual art; 3. Highlighted and discussed issues are based on challenges; any question or problems which surface have not been thought over in terms of possibilities of things happening all at one time; and 4. Medium and the method to highlight a particular issue or predicaments related to complicated bureaucracy; online applications are an alternative to get in touch directly with the Islamic institutions regarding a question or a problem.

All of the factors mentioned above become a dismal source of discussions on visual art from the perspective of Islam. The last discourse was in the 2009, and the guidelines which were produced in 1987 (Jabatan Kemajuan Islam Malaysia, 1987) has not been improved to remain at par with the local visual are development (Ramli, Masrek, Ab Gani, et al., 2017b, 2017a).

\subsection{Research Opportunities}

A research finding from the analysis on doctrinal reference contributes to a deeper explanation of characteristics that are discussed about the presentation of visual artwork based on the Islamic perspective. The following are opportunities that can be the basis of further research in the future: 1 . Contemporary visual art in Malaysia - a comprehensive study that involves various visible subjects and styles relative to the current situation in Malaysia must be conducted to obtain the views from Islamic Shariah scholars. This is regardless of artwork that is two dimensional, three dimensional as well as four dimensions; 2. Malaysian visual field - a study encompassing the other situations of visual fields from the perspective of Islamic Shariah must be carried out on advertisement, animation, fashion, and clothing as well as other relevant aspects; 3 . Medium in the production of visual artwork - medium and materials in the process of producing visual art artwork must be given due attention in ensuring the items are Shariah-compliant; and 4. The method of sales and purchases of visual artwork - purchasing a visual art and owning it is a process that must be explicitly reviewed in the issues of exhibitions, storage, sale and purchase agreement, and others.

\subsection{Conclusion}

The objective of this research which is to systematically study the doctrinal reference regarding visual art from various Malaysian Islamic institutions and analyze the content of all collections (objective 1) about visual art through the lens of Islamic shariah, is achieved. For this purpose, the researchers have created the research framework, analyzed all documents from Malaysian Islamic 
institutions, and the findings are comprehensively presented via a structured literature review approach. The researchers have the opportunity to identify potential future studies. Based on this study, the structured literature review approach is extremely useful to gather all documents systematically. Such a well-structured procedure has resulted in very comprehensive results.

Thus, from this study, it is conclusive that a comprehensive research of the current visual art scene and its Islamic Shariah perspectives must be conducted. The researchers hope that the findings of this study will contribute to future research, especially in other fields in visual art and anything related to visuals from the Islamic Shariah lens.

\section{Acknowledgments}

This research work is supported by the Ministry of Higher Education Malaysia from Fundamental Research Grant Scheme (FRGS) [Ref. No. 600-IRMI/FRGS 5/3 (002/2017)]; and partly financially supported from Institute of Quality and Knowledge Advancement (InQKA), Universiti Teknologi MARA; and the author would like to express their gratitude to Faculty of Art and Design, Universiti Teknologi MARA, Perak Branch, Seri Iskandar Campus; and Institute of Research Management and Innovation, Universiti Teknologi MARA Shah Alam for managing the fund.

\section{References}

Commissioner of Law. Federal Constitution. , Pub. L. No. 3 (1) \& (2) (2010).

Commissioner of Law Revision. National Visual Arts Development Board Act 2011. , Pub. L. No. Act 724 (2015)

Dasar Kebudayaan Kebangsaan. (1971). Retrieved July 21, 2020, from Pejabat Perdana Menteri Malaysia website: https://www.pmo.gov.my/ms/2019/07/dasarkebudayaan-kebangsaan/

Esa, S. (1997). Islam and the politics of art in post-independence Malaysia (University of Temple, USA). Retrieved from http://search.proquest.com.ezaccess.library.uitm.edu. my/docview/304396406?accountid=42518

Hamidon, N. A. (2012). Islamic calligraphy in contemporary art of Malaysia. Universiti Teknologi MARA, Shah Alam, Malaysia

Hussain, A. A. (2012). Manhaj Ilmu Fiqah \& Usul Fiqah. Kuala Lumpur: Telaga Biru Sdn. Bhd.

Jabatan Kemajuan Islam Malaysia. (n.d.). Fatwa / Pandangan Hukum. Retrieved July 21, 2018, from e-SMAF Sumber Maklumat al-Ahkam al-Fighiyyah website: http://e-smaf.islam.gov.my/e-smaf/index.php/main/mainv1/fatwa/3

Jabatan Kemajuan Islam Malaysia. (1987). Garis Panduan Dan Penjelasan Mengenai Seni Tampak Dari Kaca Mata Islam. Retrieved December 20, 2019, from eSMAF Sumber Maklumat al-Ahkam al-Fiqhiyyah, Majlis Kebangsaan Bagi Hal Ehwal Ugama Islam Malaysia website: http:/le-smaf.islam.gov.my/esmaf/index.php/main/mainv1/garis_panduan/7

Kowalczyk, M. (2017). Study A: A Structured Literature Review on Business Intelligence and Analytics from a Decision Process Perspective. In The Support of Decision Processes with Business Intelligence and Analytics (pp. 15-29). https://doi.org/10.1007/978-3-658-19230-3_2

Mahamood, M. (2001). Seni Lukis Moden Malaysia: Era Perintis hingga Era Pluralis (1st Editio). Kuala Lumpur, Malaysia: Utusan Publications \& Distributors Sdn Bhd.

Mahamood, M. (2005). Pendekatan Sejarah dan Kritikal Seni Visual. Prosiding Seminar Seni Visual Kebangsaan 2005. Pulau Pinang: Pusat Pengajian Seni, Universiti Sains Malaysia.

Majis Agama Islam Selangor. (1989). BAHAGIAN II - MAJLIS AGAMA ISLAM SELANGOR Pihak Berkuasa Dalam Hal Ehwal Agama. Retrieved July 25, 2018, from Enakmen Pentadbiran Perundangan Islam 1989 website:

http://www2.esyariah.gov.my/esyariah/mal/portalv1/enakmen2011/State_Enact_Ori.nsf/100ae747c72508e748256faa00188094/0473978d8b57e6164825703c000f31d9 ?OpenDocument

Mohd Zain, D. H. (1996). Safavid Qur'ans: Style and Illumination (University of Edinburgh). Retrieved from http://hdl.handle.net/1842/21628

Mohd Zain, D. H. (2000). Katalog Pameran Bentuk dan Makna. Shah Alam, Selangor: Jabatan Seni Halus, Universiti Teknologi MARA.

Mohd Zain, D. H. (2006). Seni Islam (6th Editio). Batu Caves, Selangor: Univision Press Sdn.Bhd.

Mohd Zain, D. H. (2012). Ta'biran dan Penghayatan Seni Islam. In Taman Nurani: Nafas Keislaman dalam Seni Kontemporari Malaysia. Kuala Lumpur: Galeri Petronas.

Noh, L. M. M., Haron, H., Samian, A. L., \& Hasan, A. (2015). Formalistic as an analysis method in signifying the malay cultural symbol in Malaysian modern art of paintings. Mediterranean Journal of Social Sciences, 6(4), 30-38. https://doi.org/10.5901/mjss.2015.v6n4s2p30

Ocvirk, O., Stinson, R., Wigg, P., Bone, R., \& Cayton, D. (2006). Art Fundamentals Theory and Practice (Tenth). School of Art, Bowling Green State University: Mc Graw Hill.

Ramli, I., Masrek, M. N., Ab Gani, M. A. A., Md Zain, D. H., Osman, M. R., Mohktar, M., ... Mohd Zamri, Z. (2017a). Visual Art From The Perspectives Of Islamic Shariah: A Need Assessment Analyses. In F. Uslu, T. Güçlü, M. Özdemir, K. Altan, \& S. Aslan (Eds.), INTCESS 2017- 4th International Conference on Education and Social Sciences (pp. 276-276). Retrieved from http://www.ocerint.org/intcess17_epublication/abstracts/a196.html 
Ramli, I., Masrek, M. N., Ab Gani, M. A. A., Md Zain, D. H., Osman, M. R., Mohktar, M., ... Mohd Zamri, Z. (2017b). Visual Art From The Perspectives Of Islamic Shariah: A Need Assessment Analyses. IJASOS- International E-Journal of Advances in Social Sciences. https://doi.org/10.18769/ijasos.309687

Ramli, I., Masrek, M. N., Gani, M. A. A. A., Zain, D. H. M., Mokhtar, M., \& Osman, M. R. (2017). Visual Art from the Perspectives of Islamic Shariah: A Proposed Model. Advanced Science Letters, 23(4), 3029-3032. https://doi.org/10.1166/asl.2017.7642

Ramli, I., Masrek, M. N., Mokhtar, M., Zain, D. H. M., Osman, M. R., \& Zamari, Z. M. (2019). THE CONCEPT OF HALAL IN VISUAL ART MARKETING STRATEGY: A RESEARCH MODEL DEVELOPMENT. IJASOS- International E-Journal of Advances in Social Sciences, 900-907. https://doi.org/10.18769/ijasos.591910

Sanusi, K. (2000). Visual art education in Malaysia (University of Temple, USA). Retrieved from http://search.proquest.com.ezaccess.library.uitm.edu.my/docview/304654369?accountid=42518

Sanusi, K. (2016). Encountering globalisation: the work of Sulaiman Esa from the 1950s to 2011. In C. A. Brebbia \& A. M. Boquera (Eds.), Islamic Heritage Architecture and Art. WIT Transactions on The Built Environment:1st International Conference on Islamic Heritage Architecture and Art (IHA 2016) (pp. 23-34). Retrieved from https://www.witpress.com/books/978-1-78466-083-3

Sayyid Muhammad, A. (1984). Islamization of Visual Art. International Conference of Islamization of Knowledge, 483-496. Saudi Arabia: International Islamic Publishing House.

Seyedi, B. M., Hamidon, N. A., \& Ross, L. N. (2017). A comparative study od Islamic calligraphy painting in Malaysia and Iran. Jurnal Pengajian Melayu.

Shaffril, H. A. M., Krauss, S. E., \& Samsuddin, S. F. (2018). A systematic review on Asian's farmers' adaptation practices towards climate change. Science of the Total Environment. https://doi.org/10.1016/.scitotenv.2018.06.349

Vom Brocke, J., Simons, A., Niehaves, B., Riemer, K., Platffaut, R., \& Cleven, A. (2009). Reconstructing the giant: On the importance of rigour in documenting the literature search process. 17th European Conference on Information Systems, ECIS 2009.

Wan Mohd Daud, W. S. A. (2017). An axiological study on islamic visual art in Malaysia from 1957 to 1999. Universiti Teknologi MARA.

Wan Mohd Daud, W. S. A., Mohd Zain, D. H., \& Amin, R. (2013). Study on the Malaysian Islamic visual art: The contemporary view. International Journal of Education and Research.

Wan Mohd Daud, W. S. A., Mohd Zain, D. H., \& Amin, R. (2014). A Preliminary Study on Axiology in the Malaysian Islamic Visual Art. Global Journal of Human-Social Science, 14(2), 22-26. Retrieved from https://globaljournals.org/GJHSS_Volume14/4-A-Preliminary-Study-on-Axiology-in-the-Malaysian.pdf 